\title{
Future trend of mineral industries development in Indonesia
}

\author{
Ukar Wijaya Soelistijo ${ }^{1}$, La Ode Aswandi ${ }^{2}$ \\ ${ }^{1}$ University of Islam Bandung (UNISBA), Bandung Indonesia, Institute of Technology Bandung (ITB), Bandung Indonesia, Mineral and \\ Coal Technology R\&D Center (MCTRDC), Bandung Indonesia \\ ${ }^{2}$ Institute of Technology Bandung; PT. Tambang Indonesia Sejahtera, Indonesia
}

\section{Email address:}

ukar@tekmira.esdm.go.id (U.W. Soelistijo), ukarws@gmail.com (U. W. Soelistijo), aswandi@students.itb.ac.id (L. Aswandi), wandyxx@gmail.com (L. Aswandi)

\section{To cite this article:}

Ukar Wijaya Soelistijo, La Ode Aswandi. Future Trend of Mineral Industries Development in Indonesia. Earth Sciences. Vol. 3, No. 2, 2014, pp. 58-67. doi: 10.11648/j.earth.20140302.14

\begin{abstract}
The aim of this study is to figure out the vision of effort of utilizing the remainder of the available mineral asset in the country, where Indonesia is necessarily seeking new opportunity toward developing mineral industry (hydrocarbon, metal, and non-metal) such as fine chemical industry, alloy (stainless/tool steel), fibre, ceramic block, super/semiconductor in the purpose of supporting super downstream industry that could produce massive mineral products containing high added value. Moreover, those downstream industries require high quantity and quality of minerals as raw material. The methodology applied in this study is based on a descriptive analytical method combined with dynamic commodity models to find the problems encountered in the effort to gain highest added value in mineral utilization.
\end{abstract}

Keywords: Indonesia, Mineral Resources, Super-Downstream Industry, Added Value

\section{Introduction}

Two key words in the title are future and mineral industry, that would be studied in this article. In this article what so called minerals are including fossil energy mineral resources. In principle, the future constitutes era of globalization that as has been wide spread flared up within the last one human live period or era, while human live period per se has performed since the last 800 human live periods. One human live period is around say 60-70 years of age.

Alfin Toffler divides human live period that has spread since around 50,000 years in the past or around 800 human live periods. Within 799 human live period that initiated by stone age or living in the cave within 650 human live periods, then continued by the transition of engage in planting as early stage of agricultural cultivation within 140 human live periods, and era of metal or metal period when typing machine was initially utilized within 70 human live periods and followed by utilizing electrical machine within 3 human live period. And then human live is in the industrial era up to the present time as within the current one human live period.

In the last present live period, human start to begin with entering the era of modern industry or superindustry all at once in the transition of the present information era and supermodern industry that are mostly utilizing alloy or alloy of superconductor and semi conductor as well.

Red line in the path of human live period is measured based on the stage of utilizing mineral that is stone age, era of metal and era of industry and information era or era of super and semiconductor. Era of information constitutes era of telecommunication and computer where "chip" technology is as its back bone, and the raw materials of chip are rare elements or rare metal elements that are extracted from rare minerals like monazite containing yttrium, or other minerals containing scandium, europium, strontium, lantahnium, and its certain kind that function as super or semiconductor (Soelistijo, et al., 1993).

The aim of this article is to expose result of thought to observe about widening the outlook on the direction of utilization policy of various kinds of mineral and energy resources that actually contained in the Indonesia's earth facing the future of nation.

Toward the future, human still needs the three kinds of minerals as a whole, either minerals of energy, metal, nonmetal or industrial minerals. Minerals of energy either 
hydrocarbon (such as oil and gas, coal) or non-hydrocarbon (nuclear) are still flare up to the end of $21^{\text {st }}$ century, as far as its reserves are still found out, all at once the nuclear energy constitutes as the bridge of future energy toward the intensive utilization of renewable non-mineral energy such as geothermal, solar, wind, ocean wave, due to the limited non-renewable mineral energy (Figures 1, 2 and 3).

While coal could be utilized as bridge of energy from era of oil and gas energy toward era of new and renewable energy, because Indonesia owns coal resources to meet consumption for 100-150 years in the era of post oil and gas (Figure 3). Metallic mineral that resulting various alloys is atill required to suppport manfacturing industry to meet the human demand. Non-metallic mineral would still be required for the development of industry that requires intensive rare metallic elements such as yttrium, lanthanum, europium, gadolinium, beryllium, zircon and so on.

\section{MINERAL AND ENERGY RESOURCES DISTRIBUTION IN INDONESIA}

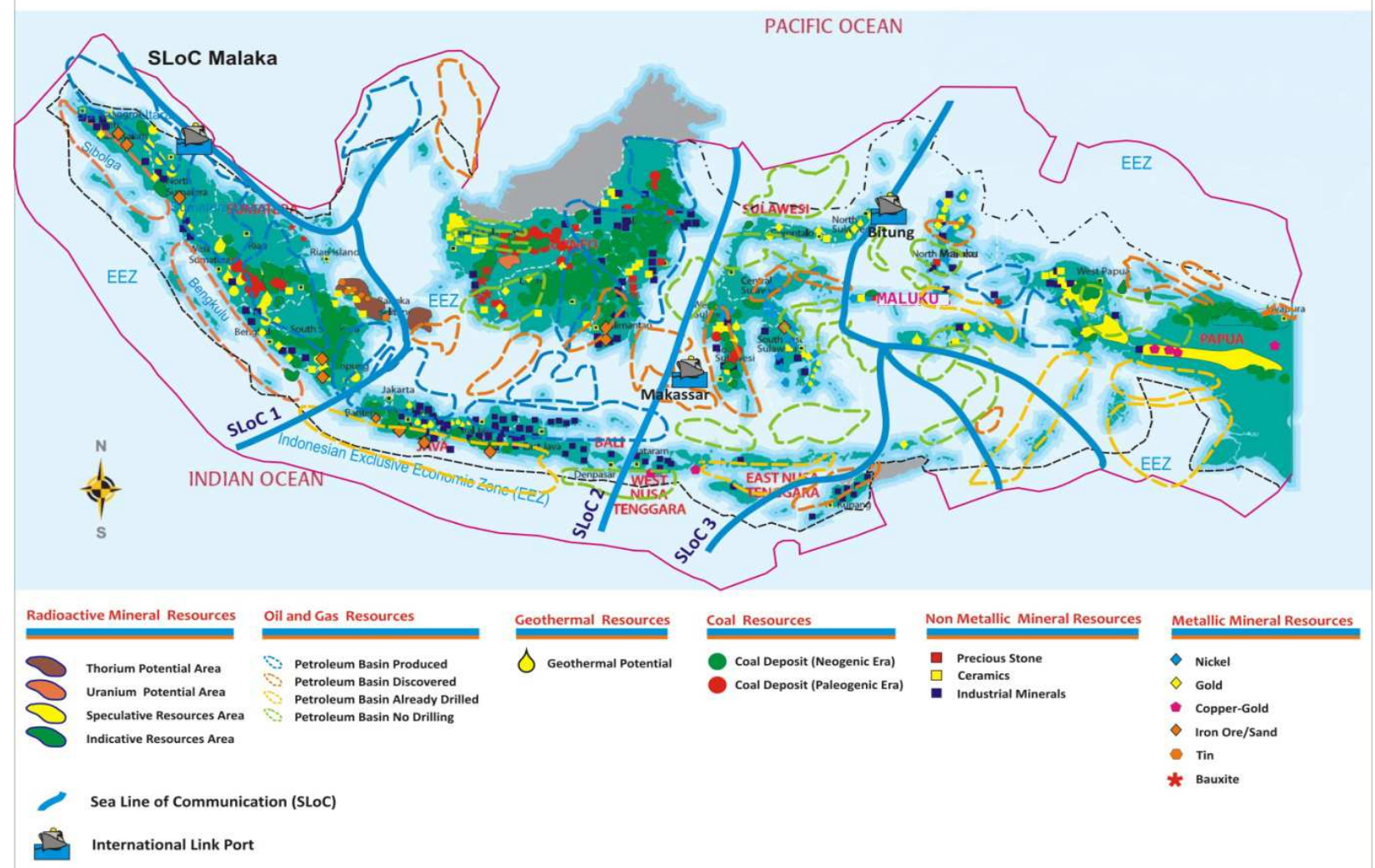

Figure 1. Indonesia Mineral and Energy Resources Distribution Map (Sources: Ministry of Energy and Mineral Resources, Indonesia, 2011, reprocessed).

Hydrocarbon Resources

$\underline{\text { Utilization }}$

Non Hydrocarbon Resources

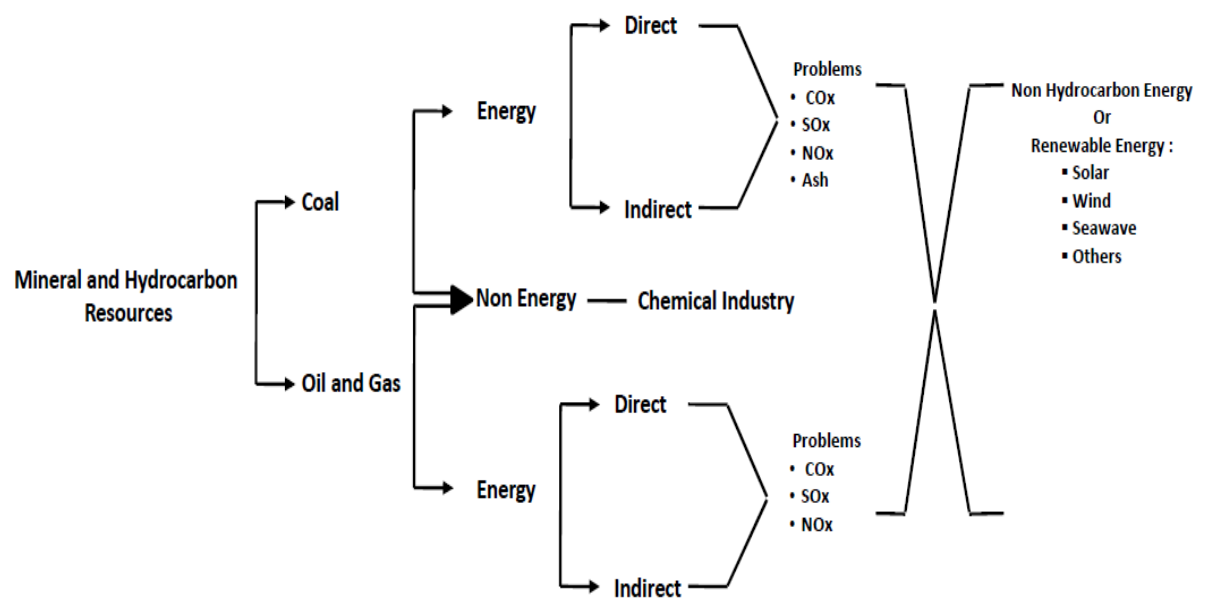

Figure 2. Energy Resources (Sources: World Energy Outlook 2007, reprocessed). 


\begin{tabular}{|c|c|c|c|}
\hline & & World & Indonesia \\
\hline \multirow{4}{*}{ Coal } & Proven Reserves & 765.4 Billion Tonnes & 28.02 Bilion Tonnes (2012) \\
\hline & Geological Resources & 10.1 Trillion Tonnes & 120.34 Billion Tonnes (2012) \\
\hline & Hard Coal/Anthracite & 7.7 Trillion Tonnes & \\
\hline & Brown Coal/Lignite & 2.4 Billion Tonnes & \\
\hline \multirow{9}{*}{ Oil } & Resources & $435 \mathrm{GT}(\approx 2,044$ Billion BOE) & 56.6 Billion Barrels (2010) \\
\hline & Potential Reserves & & 4.04 Billion Barrels (2012) \\
\hline & Proved Reserves & 1,668.9 Billion Barrels & 3.7 Billion Barrels (2012) \\
\hline & Middle East & 807.7 Billion Barrels & \\
\hline & North America & 220.2 Billion Barrels & \\
\hline & South and Central America & 328.4 Billion Barrels & \\
\hline & Europe and Eurasia & 140.8 Billion Barrels & \\
\hline & Africa & 130.3 Billion Barrels & \\
\hline & Asia Pacific & 41.5 Billion Barrels & \\
\hline \multirow{3}{*}{ Natural Gas } & Resources & 10,509 Exajoules $(\approx 9,850,891 \mathrm{TSCF})$ & \\
\hline & Proved Reserves & 6,614.1 TSCF & 104.71 TSCF \\
\hline & Potential Reserves Reserves & & $48.18 \mathrm{TSCF}$ \\
\hline
\end{tabular}

Source:

1) Handbook of Energy \& Economic Statistics of Indonesia 2012

2) Indonesian Mineral and Coal Statistics 2012, Ministry of Energy and Mineral Resources

3) Statistical Review of World Energy 2013, British Petroleum

4) World Energy Outlook 2008 Reprocessed

Figure 3. World Energy Resources/Reserves.

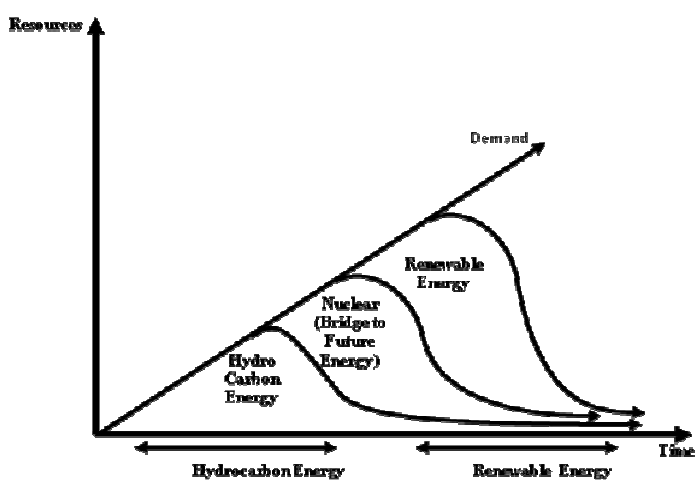

Figure 4. Energy Transition.

\section{Theory, Methodology and Mindset}

\subsection{Theory and Mindset}

The future constitutes era of globalization at once also as era which has several characteristics such as:

- complete competitiveness either in the aspect of quantity, quality, "price" in the wide meaning or "just in time delivery".
- trend of ignoring the various constraints or "3 B's" or barrier, boundary and border) in terms of economics/sector, state, and geography toward multile networks or "2 N's" (network of networks).

- $\quad$ the ability in free investment and trade; and

- $\quad$ the glowing global environment that brings disorder to the old theory and the condition of being related to nation and state life (Soelistijo, 2013).

Shortly speaking, era of globalization constitutes epoch of globalizing human life and civilization with its dynamic of modern norms.

Understanding of globalization can be described in simple terms where at an avenue in a city there are different kinds of restaurant, typical of the region (Sunda, Java, Padang as local types of food) to another Mandarin Asia, Thailand, Korea, Japan, and even Europe, Africa and others. Even this can also happen only in a restaurant, all types of merchandise that is peddled these foods are complete, and live customer order within the shortest possible time available. On the other side globalization of culture, for example, it that the various types of food replaced by culture, for example performing arts cultures in the world trade center, that is globalization in culture. Even 
"gamelan" as traditional Javanese music has been commonly combined with modern music to perform a song, and nice to be heard.

Within any age, human are always "measured", and in the era of globalization human is also "measured". Thereby, improving the quality of human resources is measured by the benchmarks of the mastery of science and technology as well as the accompaniment of mental and moral qualities. People are expected to have a vision for the future, and not just as a resource (or resources), but people with high creativity, according to the phrase "Resources are limited, creativity, however, is unlimited". Man is the central point at any age, even creates the era of globalization itself with different dynamics. Inside one of the last human lifetime and the lifetime of the next, so the acceleration of modernization not absurdly tall, in order to meet human needs for goods (commodities) and services including mineral commodities.

In today's globalization there is a "competition/economic war" or "competition/trade war" , especially in the field of telecommunications, super and semiconductor, and automotive industries. In semiconductor commodity it happens because it is the backbone of "chips" technology in the electronics industry, which is the supporting technology of information ages. In telecommunications which is an important tools of the information age, has been using the outer space as a new area with cutting-edge technology that is developing very fast. This field requires a new superconductor materials such fibre. Automotive industry will still require a variety of metal alloys, ceramic block for a replacement engine blocks are still made of steel. The need for materials in the supermodern industrial requires materials technology that will need to be developed and will be developing very fast in the future.

\subsection{Methodology}

The method used in this observation is accompanied by a descriptive analytical method combined with dynamic commodity models to find out the problems encountered in the effort to gain highest added value in mineral utilization of both metals, minerals and energy. The simple meaning of added value is the result of techno-economic transformation from the initial condition of mineral resources and commodity toward the condition with the greater value in terms of economy, utilization and usefulness than before, then this new condition would contribute positive impact upon the economic, social and culture at the level of global, regional, national and local.

The conventional commodity model could dynamicly be described as follows (Labys, 1973; Soelistijo, 1991, 2003):

Demand for commodity: D = d ( $\left.\mathrm{D}_{-1}, \mathrm{PW}, \mathrm{PS}, \mathrm{A}, \mathrm{TF}\right)$;

Supply of commodity: $\mathrm{Q}=\mathrm{q}\left(\mathrm{Q}_{-1}, \mathrm{PW}_{-1}, \mathrm{U}, \mathrm{NR}, \mathrm{Z}\right)$;

Price of commodity: $\mathrm{P}=\mathrm{p}\left(\mathrm{P}_{-1}, \mathrm{D}, \mathrm{I}\right)$;

Stock of commodity: $\mathrm{IC}=\mathrm{IC}_{-1}+\mathrm{Q}-\mathrm{D}$;

Supply-demand equation: $\mathrm{C}=\mathrm{Q}+\mathrm{M}-\mathrm{X}+(-) \mathrm{S}$; where: $\mathrm{D}=$ demand; $\mathrm{D}_{-1}=$ historical demand; $\mathrm{PW}=$ world price; $\mathrm{PS}=$ price of substitute; $\mathrm{A}=$ economic activity; $\mathrm{TF}=$ technological factor; $\mathrm{Q}=$ supply; $\mathrm{Q}_{-1}=$ historical supply; $\mathrm{PW}_{-1}=$ hidtorical world price of commodity; $\mathrm{U}=$ large area of land; $\mathrm{NR}=$ reserves of natural resources; $\mathrm{Z}=$ policy; $\mathrm{P}=$ price of commodity; $\mathrm{P}_{-1}=$ historical price trend of commodity; I = Inventory; IC = stock or inventory of commodity; $\mathrm{IC}_{-1}=$ historical stock or inventory; $\mathrm{C}=$ consumtpion; $\mathrm{M}=$ imports; $\mathrm{X}=$ exports; $\mathrm{S}=$ Stock.

Since policy of mineral utilization of any country would produce natural resources including minerals at the certain level of extraction, then its resources should be dynamically explored from time to time to meet the increasing demand.

\section{Results and Discussion}

There is an economic trend that the use of mineral hydrocarbons, such as coal, oil and natural gas as energy will be further reduced in the future, with the rise of the fine chemical industry that produce higher value-added materials than simply burned as an energy material, although petroleum reserves in the Middle East, Siberia, Antarctic is sufficient until the end of the 21 st century. In the field of energy, before being able to develop biotechnology-based energy, Indonesia needs to develop geothermal energy resources as the primary energy in addition to coal, because geothermal reserves are quite large (about 27,000 MWe) (Directorate of Mineral and Coal Enterprises, 2009; Anonymous (i), 2012) and did not produce carbon dioxide gas as the main constituent of greenhouse gases. In the case of natural oil and gas basin Indonesia owns around 60 basins, 39 basins of it have been well explored and produced, but the remainder or 21 basins are still not explored yet (Sayogyo, 1999; Direktorat Jenderal Minyak dan Gas Bumi,1995). There are still possiblities of finding out other promising oil and gas resources especially in the offshore areas. And these potentials could answer the present depleted oil and gas reserves at the level of around 3.7 billion barrels only. To response this condition, the government of Indonesia has invited the private companies to do grass root exploration.

In term of synthetic crude oil from coal liquefaction, where the effort of the Indonesian government in cooperation with the government of Japan has been launched since 1980's, and in the end of 1990's it has been found out that the feasibility study of production cost of synthetic crude oil were between US\$ 21-25 per barrel resulted from several coal locations in Indonesia. In that time it was studied that if the price of natural crude oil was US\$ 35 per barrel then the coal liquefaction would be economically feasible, where the price of crude oil was just about US\$ 20-22/bbl. There would be opportunity of Indonesia to do so as far as the current world price of crude oil is above US\$ 70 per barrel.

In the case of possibility of utilizing nuclear energy especially for power plant, the government of Indonesia is still very allert to do so, because the reluctancy of the community to apply nuclear energy in the country. 
However, the government has been doing feasibility study the application of nuclear energy for the future, in case if it is required at any time.

Here is certain indication that there is radioactive mineral resources available in Indonesia, but it's availability not so necessary if Indonesia should be developing nuclear power plant in the future. It is due to the very effective utilizing radio active element as fuel source in the power plant that could be imported from or in cooperation under electricity production sharing contract with other radio active elements producing countries under the international proliferation treaty.

In general, in metal and mineral commodities there is a decreasing trend of rate of the mineral use intensity in the industry as the technological advances that improve the efficient use of materials. Moreover, this condition would also be acquainted with metals and metals substitution as well as between metal commodities and fiber products or non metallic commodities. For example, aluminum replacing tin in tin plate although lately turned back replacing aluminum in tin plate, in addition to aluminum replace steel as a construction material because it is lighter. $\mathrm{Nb}-\mathrm{Ti}$ ceramic fiber replaces copper as a conductor, because fiber is lighter (70 kg fiber $/ 1000 \mathrm{~kg}$ of copper) with 50 times higher conductivity even at much lower temperatures, and $40 \%$ lower in price. Banka Belitung islands known as the Tin Island, but also contained the monazite mineral as associated minerals, it contains thorium (radioactive elements) and yttrium. In the iron sand deposits in Kulon Progo, DI Yogyakarta, there is mineral ilmenite (FeTiO3) deposit containing light metals titan that can be used as a wall coating for aircraft or spacecraft (Soelistijo, et al., 1993, 1999, 2003,2013, 2014).

In the future stainless steel alloy industry is still have market because the automotive industry is still growing strong, despite industrial ceramic block will replace the engine steel block. In Outer Space industry needs high termperature resistant light metals, for example, titan, vanadium and others, beside precious metals such as gold as an absorber of cosmic rays, but gold also remained strong as precious metals with special use.

It seems that in the future need to be developed in fast of non-metallic mineral extraction industry which produces super and semiconductor which is highly needed in the supermodern industry, chip technology and such, which is the foundation of telecommunications industry, aerospace and information industry. Certainly, that there is also huge resources of industrial minerals in the country as the source of rare (earth) metal elements that needs certain seriousness to developing its downstream technology application for extracting those rare elements for supporting of developing advanced nano technology.

Industrial minerals are subject to economic provisions, that mineral commodities is "derived demand" and downstream sectors that need it. Thus, if the downstream industry are competing to develop the efficient use of minerals through advanced technology, by itself the use of minerals will decrease or no longer needed and because there is substitution technology that utilizes non-mineral materials. For example, the linkages between the automotive industry as downstream industries of steel industry (Figure 5). Steel industry requires raw material of iron ore. But iron ore reserves declined due to a decrease in the amount of iron ore resources of the world, thus causing further rise in the price of iron ore $\left(\mathrm{Pb}^{*}\right)$ affecting an increasing prices of steel ( $\left.\mathrm{Ps}^{*}\right)$. With the increasing demand in automotive will increase the price of steel with conditions supply tend to decrease, because the amount of world iron ore reserves are decreasing. This resulted in the increasing price of automotive ( $\left.\mathrm{Pa}^{*}\right)$. In July 2010 automotive price rose about $20 \%$ because the increasing price of steel, with a background of the increase of automotive demand nearly in all countries. Increasing the capacity of the steel plant requires a relatively long time similarly as increasing the production of iron ore mined. A similar trend is followed by all commodities especially which materials fully contains of minerals, such as ceramics, construction materials from aluminum, tin, gold jewelry, drilling machine with diamond drill bits etc.

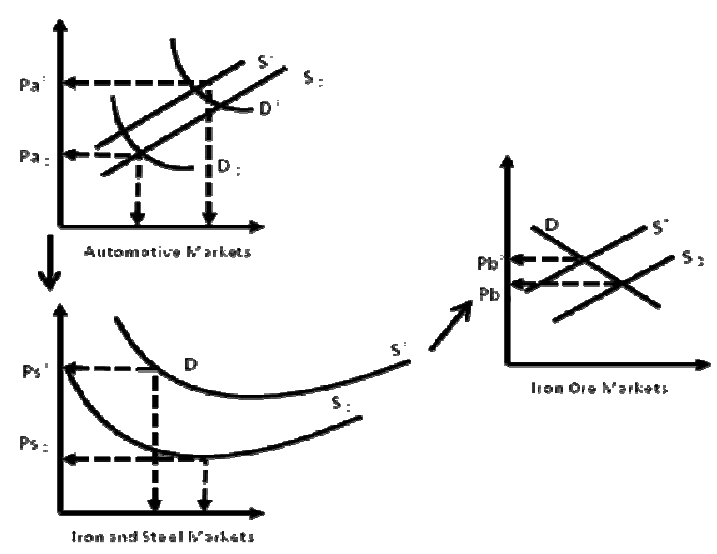

Figure 5. Correlation between Automotive Market, Iron and Steel Market and Iron Ore Market.

As an illustration (Table 1, Figure 6), the Indonesian non-oil balance of trade in the pre crisis 1985-1997 generally deficit is between US\$ 1.5 billion to US\$ 5.4 billion, but in 1993, 1994, and in 1997 a surplus of around US\$ 920 million, approximately US\$ 744 million and approximately US\$ 4 billion. Precisely during the crisis of 1997-1999 surplus of non-oil trade of US\$ 16.3 billion to US\$ 20.3 billion. In the 2000-2011 period Indonesia's trade surplus amounted to between US\$28.6 billion to US\$ 26.1 billion, but in 2012 Indonesia had the first trade deficit of US\$ 1.6 billion or there is a symptom of decrease. Overall, balance of trade of oil and gas and mineral commodity/mining general which help Indonesia's balance of trade. 
Table 1. Indonesian Balance of Trade 1984 - 2012 (US\$ Million).

\begin{tabular}{|c|c|c|c|c|c|c|c|}
\hline Year & Total Export & Total Import & Nett Total & $\begin{array}{l}\text { Oil and Gas } \\
\text { Balance* }^{*}\end{array}$ & $\begin{array}{l}\text { Non Oil and Gas } \\
\text { Balance }^{* *} \text { ) }\end{array}$ & Export Growth & Import Growth \\
\hline 1 & 2 & 3 & 4 & 5 & 6 & 7 & 8 \\
\hline 1984 & $21,887.8$ & $13,882.1$ & $8,005.1$ & $13,321.3$ & $(5,315.6)$ & 3.51 & $(15.10)$ \\
\hline 1985 & $18,580.7$ & $10,259.1$ & $8,321.6$ & $11,436.2$ & $(3,114.6)$ & $(15.11)$ & $(26.10)$ \\
\hline 1986 & 14.8 & $10,718.4$ & $4,086.6$ & $7,190.2$ & $(3,103.6)$ & $(20.11)$ & 4.48 \\
\hline 1987 & $17,135.6$ & $12,370.3$ & $4,765.3$ & $7,488.1$ & $(2,722.8)$ & 15.74 & 15.41 \\
\hline 1988 & $19,218.5$ & $13,248.5$ & $5,970.0$ & $6,772.5$ & $(802.5)$ & 12.16 & 7.10 \\
\hline 1989 & $22,158.9$ & $16,359.6$ & $5,799.3$ & $7,483.6$ & $(1,684.3)$ & 15.30 & 23.48 \\
\hline 1990 & $25,675.3$ & $21,837.1$ & $3,838.2$ & $9,150.6$ & $(5,312.4)$ & 15.87 & 33.48 \\
\hline 1991 & $29,142.4$ & $25,868.9$ & $3,237.5$ & $8,584.6$ & $(5,311.1)$ & 13.50 & 18.46 \\
\hline 1992 & $33,966.9$ & $27,279.7$ & $6,687.2$ & $8,555.8$ & $(1,868.6)$ & 16.55 & 5.45 \\
\hline 1993 & $36,823.0$ & $28,327.8$ & $8,495.2$ & $7,575.3$ & 919.9 & 8.41 & 3.84 \\
\hline 1994 & $40,053.4$ & $31,983.5$ & $8,069.9$ & $7,326.2$ & 743.7 & 8.77 & 12.90 \\
\hline 1995 & $45,481.0$ & $40,628.7$ & $4,789.3$ & $7,553.6$ & $(2,764.3)$ & 13.39 & 27.03 \\
\hline 1996 & $49,814.8$ & $42,928.5$ & $6,886.3$ & $8,126.3$ & $(2,239.9)$ & 9.68 & 5.66 \\
\hline 1997 & $53,443.6$ & $41,679.8$ & $11,763.8$ & $7,968.4$ & $4,065.4$ & 7.28 & (2.91) \\
\hline 1998 & $48,847.6$ & $27,336.9$ & $21,510.7$ & $5,218.4$ & $16,292.3$ & $(8.60)$ & (34.41) \\
\hline 1999 & $48,665.4$ & $24,003.3$ & $24,662.1$ & $6,111.1$ & $18,551.0$ & $(0.37)$ & (12.19) \\
\hline 2000 & $62,124.0$ & $33,514.8$ & $28,609.2$ & $8,347.1$ & $20,262.1$ & 27.66 & 35.30 \\
\hline 2001 & $56,320.9$ & $30,962.1$ & $25,358.8$ & $7,164.5$ & $18,194.3$ & $(9.34)$ & $(7.62)$ \\
\hline 2002 & $57,158.8$ & $31,288.9$ & $25,869.9$ & $5,586.9$ & $20,283.0$ & 1.49 & 1.06 \\
\hline 2003 & $61,058.2$ & $32,550.7$ & $28,507.5$ & $6,040.5$ & $22,467.0$ & 6.82 & 4.03 \\
\hline 2004 & $71,584.6$ & $46,524.5$ & $25,060.1$ & $3,913.3$ & $21,146.8$ & 17.24 & 42.93 \\
\hline 2005 & $85,660.0$ & $57,700.9$ & $27,959.1$ & $1,773.8$ & $26,185.3$ & 19.85 & 15.67 \\
\hline 2006 & $100,798.6$ & $61,065.5$ & $39,733.1$ & $2,246.6$ & $37,486.5$ & 17.67 & 5.83 \\
\hline 2007 & $114,100.9$ & $74,473.4$ & $39,627.5$ & 155.8 & $39,471.7$ & 13.20 & 21.96 \\
\hline 2008 & $137,020.4$ & $129,197.3$ & $7,823.1$ & $1,426.7$ & $6,396.4$ & 17.26 & 87.75 \\
\hline 2009 & $116,510.0$ & $96,829.2$ & $19,680.8$ & 37.6 & $19,643.2$ & (14.97) & $(25.05)$ \\
\hline 2010 & $157,779.1$ & $135,663.3$ & $22,115.8$ & 626.9 & $21,488.9$ & 35.42 & 40.11 \\
\hline 2011 & $203,496.6$ & $177,435.0$ & $26,061.1$ & 775.5 & $25,285.5$ & 28.97 & 30.79 \\
\hline 2012 & $190,020.3$ & $191,689.5$ & $(1,669.2)$ & $(5,586.9)$ & $3,917.7$ & $(6.62)$ & 8.03 \\
\hline 2013 & $182,551.8$ & $186,628.7$ & $(4,076.9)$ & $(9,633.4)$ & $8,556.5$ & (3.93) & $(2.64)$ \\
\hline
\end{tabular}

Source :

BPS, Indonesian Statistics 2013

Note : Export and Import presented in total value

*) Oil and Gas Balance = Oil and Gas Export - Oil and Gas Import

**) Non Oil and Gas Balance = Non Oil and Gas Export - Non Oil and Gas Import

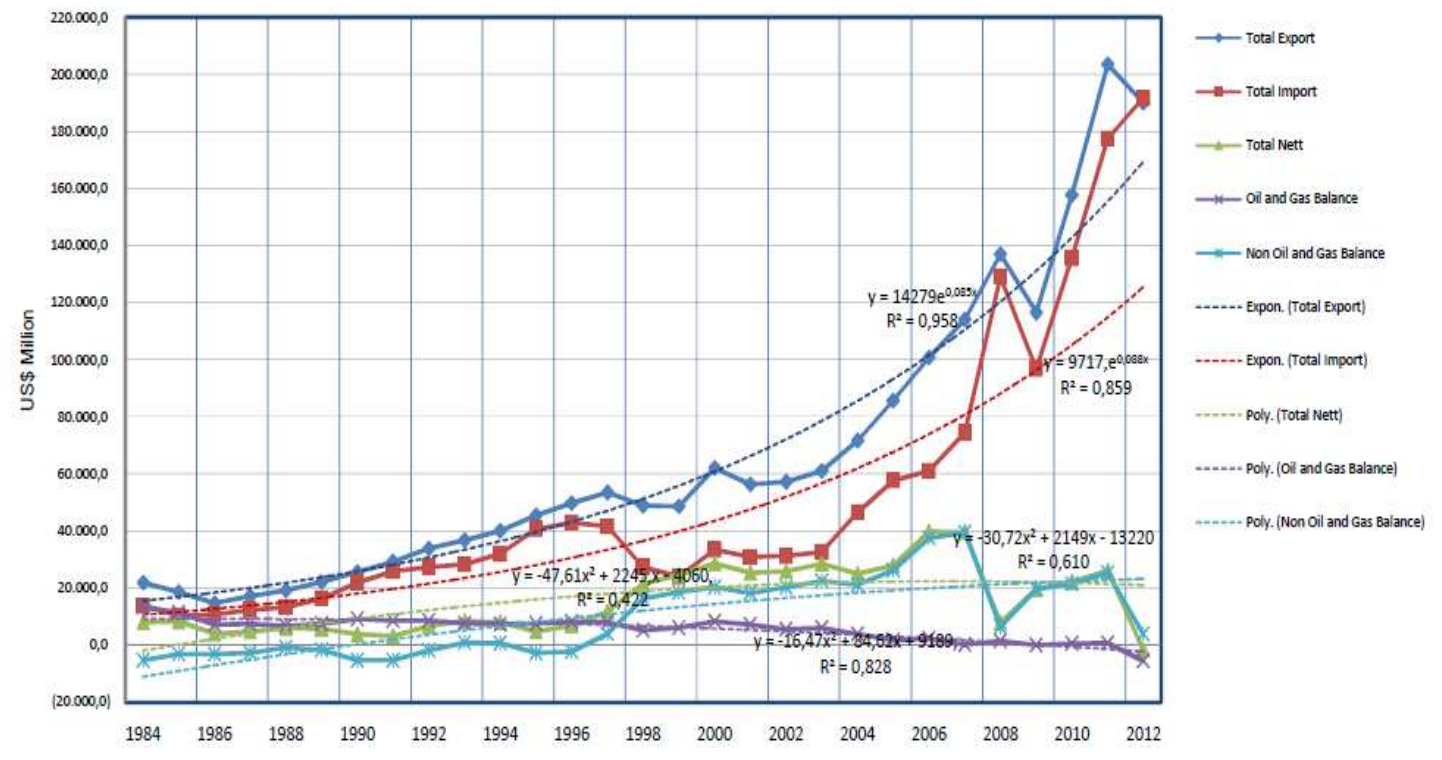

Figure 6. Indonesian Trading Trendline, 1984-2012 (US\$ Million). 
Because already surplus of about US\$ 5 billion to US\$ 10 billion each year despite decreasing trend. In 2000 oil exports contribution clearly increased due to oil prices increase in the international market so that obtain large enough windfall profits above US\$ 1 billion. In the period 2001-2011 there is a trade surplus of oil US\$ 7.16 billion till US\$ 775 million but in 2012 deficit US\$ 5.58 billion. But with the rising prices of oil and gas and world mineral commodities until 2-3 times higher, it is certain that after 2008 there will increase in balance of trade. Until now, the mineral commodity trading industry is still have a deficit or negative balance of trade around US\$ 150-230 million per year. Overall, increasing revenues of mineral commodities caused by the increasing number of the mineral requirements in related downstream industries as consumers, in addition to the increase due to rising commodity prices by the amount need not be followed by a number of supply are balanced. In Figure 6 it is figured out that the regression eaquation of the total export curve is of $\mathrm{Y}=14279 \mathrm{e}^{0.065 \mathrm{x}}$ with $\mathrm{R}^{2}=0.958$ and the total import of $\mathrm{Y}$ $=9717 \mathrm{e}^{0.068 \mathrm{x}}$ with $\mathrm{R}^{2}=0.859$. And the nett balance of trade (BOT) regression equation is of $Y=-30.72 x^{2}+2149 x-$ 13220 with $\mathrm{R}^{2}=0.610$, where the regression equation of non-oil and gas BOT is of $Y=-47.61 x^{2}+2245 x-4060$ with $\mathrm{R}^{2}=0.472$ and the regression equation of oil and gas if $\mathrm{Y}=-16.47 \mathrm{x}^{2}+84.62 \mathrm{x}+9168$ with $\mathrm{R} 2=0.828$. It indicated that the declining oil and gas BOT due to the declining its export value was compensated by the increasing non-oil and gas BOT. This condition helped the increasing trend of total or national export that higher than that of total or national import.

Moreover, the promising price of several kinds of mineral commodity would help the future national income coming from mineral sector as a whole, so that the development of this sectors are very challenging (Table 2).

In the era of globalization, export primary commodities including mineral commodities should need to be minimized and try to produce final goods for export as nonoil commodity such as finished goods with fully mineral contains.

If the decades of the 1960's is an era of Indonesian upstream mineral commodities (exports of nickel ore, bauxite, iron ore, crude oil), the 1970's era of upstreamdownstream (export of copper concentrate), 1980's downstream-upstream (exports of tin, nickel-matte, LNG), 1990's downstream activities (export tin-plate, steel bar), then the next era expected to have a very high added value commodities. In the decades of the 1980's and 1990's the average annual growth rate of the volume of export, import, production and consumption of metallic minerals, respectively $12 \%, 281 \%, 31.8 \%, 254.8 \%$, while for nonmetallic (industry) is $13.4 \%, 5 \%, 14.8 \%, 7.6 \%$ (Badan Pusat Statistik, 1980-99, 2002, 2012; Departemen Energi dan Sumber Daya Mineral, 2000). This indicates that the growth rate of non-metallic minerals consumption is still low and need to be increased to supply the downstream industry, because there is a huge potential in the country. Upstream-downstream chain supply in the minerals industry still need to be improved in the country through the acquisition and application of downstream technology (value-added processing technology), such as technologies in petrochemicals, conversion of Ca-Bentonite into Nabentonite, zeolite activation, rare elements utilization, production of ceramic blocks, production of high quality alloy (Tirtosoekotjo, et al, 1992).

Table 2. Price of several kinds of mineral commodity.

\begin{tabular}{|c|c|c|c|c|}
\hline \multicolumn{3}{|l|}{ Minerals } & Price & Unit \\
\hline \multirow{10}{*}{ Metallic } & \multicolumn{2}{|l|}{ Gold } & $1,293.29$ & US\$/ounce \\
\hline & \multicolumn{2}{|l|}{ Copper } & $6,630.50$ & US\$/tonne \\
\hline & \multicolumn{2}{|l|}{ Tin } & $23,350.00$ & US\$/tonne \\
\hline & \multicolumn{2}{|l|}{ Nickel } & $16,500.00$ & US\$/tonne \\
\hline & \multicolumn{2}{|l|}{ Aluminum } & $1,791.00$ & US\$/tonne \\
\hline & \multicolumn{2}{|c|}{ Iron Ore (fines) } & 122.38 & US\$/tonne \\
\hline & \multicolumn{2}{|c|}{ Titanium } & 13.60 & US\$ $/ \mathrm{kg}$ \\
\hline & \multicolumn{2}{|c|}{ Molybdenum } & 22.74 & $\mathrm{US} \$ / \mathrm{kg}$ \\
\hline & \multicolumn{2}{|l|}{ Zircon } & $2,075.00$ & US\$/tonne \\
\hline & \multicolumn{2}{|l|}{ Zirconium } & 91.00 & US\$ $/ \mathrm{kg}$ \\
\hline \multirow{6}{*}{$\begin{array}{l}\text { Non } \\
\text { Metallic }\end{array}$} & \multicolumn{2}{|l|}{ Zeolite } & $50-800$ & US\$/tonne \\
\hline & \multicolumn{2}{|l|}{ Feldspar } & 77.00 & US\$/tonne \\
\hline & \multicolumn{2}{|l|}{ Sulphur } & 124.00 & US\$/tonne \\
\hline & \multicolumn{2}{|l|}{ Bentonite } & 65.00 & US\$/tonne \\
\hline & \multicolumn{2}{|l|}{ Kaolin } & 151.00 & US\$/tonne \\
\hline & \multicolumn{2}{|c|}{ Phosphate (rock) } & 91.40 & US\$/tonne \\
\hline \multirow{8}{*}{$\begin{array}{l}\text { Rare } \\
\text { Earth } \\
\text { Elements }\end{array}$} & \multirow{6}{*}{ Monazite } & Lanthanum & 8.42 & $\mathrm{US} \$ / \mathrm{kg}$ \\
\hline & & Cerium & 8.49 & US\$ $/ \mathrm{kg}$ \\
\hline & & Neodymium & 65.71 & US\$ $/ \mathrm{kg}$ \\
\hline & & Dysprosium & 561.43 & $\mathrm{US} \$ / \mathrm{kg}$ \\
\hline & & Terbium & 954.29 & $\mathrm{US} \$ / \mathrm{kg}$ \\
\hline & & Europium & $1,110.71$ & $\mathrm{US} \$ / \mathrm{kg}$ \\
\hline & \multicolumn{2}{|l|}{ Ilmenite $^{*}$ ) } & $230-300$ & $\$ /$ metric ton \\
\hline & \multicolumn{2}{|l|}{ Yttrium } & $45-56$ & $\mathrm{US} \$ / \mathrm{kg}$ \\
\hline \multirow{5}{*}{ Energy } & \multicolumn{2}{|l|}{ Oil } & 104.54 & US\$/barrel \\
\hline & \multicolumn{2}{|c|}{ Natural Gas } & 6.00 & $\begin{array}{l}\text { US\$/Million } \\
\text { Btu }\end{array}$ \\
\hline & \multicolumn{2}{|c|}{ Synthetic Fuel Oil (SFO) } & $20-25$ & US\$/barrel \\
\hline & \multirow{2}{*}{ Coal } & High Rank & 80.64 & US\$/tonne \\
\hline & & Low Rank & 45.0 & US\$/tonne \\
\hline
\end{tabular}

Sources :

1)Anonymous (g), 2014, Gold-London Price Market Fix, http://www.kitco.com/scripts/hist_charts/yearly_graphs.plx, accessed April 14th, 2014.

2)Anonymous (h), 2014, Non Ferrous Metals-Historical Data, http://www.lme.com/metals/non-ferrous/historical_data, accessed April 14th, 2014.

3)Anonymous (i), 2014, OPEC Basket Price, http://www.opec.org/opec_web/en/data_graphs/40.htm, accessed April 14 th, 2014.

4) M. Humphries, 2013, Rare Earth Elements: The Global Supply Chain. 5)Anonymous (d), 2010. Industrial Minerals London.

6) Anonymous (e), 2014.Indonesian Coal Reference Price April 2014.

7)Anonymous (f), 2014.Natural Gas Spot and Futures Prices (NYMEX) Henry Hub, February 2014.

8)U.S.Geological Survey, 2014.Mineral Commodity Summaries, February 2014.

Note :

*) ilmenite in concentrate, FOB Australian Ports

**) SFO Production Cost 
In future view, with the sphere of global environment so matters pertaining to the nationality and state approach are not so quite enough through security and prosperity only, moreover if it's one only, but need a new approach, that is global environment. The approach is also applicable in the development of commodities including mineral commodity as one of the natural resources in the process of transformation into economic capital and later on as social capital for the nation, so can be utilized and beneficial for just in time.

With dozens types of minerals in Indonesia we shouldn't be over optimistic to face the future, beside there is some mineral reserves have shown indications of a "sunset industry" , for example, iron sand (Padmanegara, et al., 1983; Panggabean, et al., 1983), tin, bauxite, gold (Soelistijo, et al., 1993, 2003), but also with the environmental pressure that need to be considered through globally, since the development of the resource, the extraction process until utilization, in order to meet national and international standardization. In industrial mineral commodity trading such as ceramics and the like need to be environmentally sound. For example, if at a trade show (World Trade Fair in Berlin in the 1990's), the potential buyers of manufactured products i.e. ceramics from Indonesia interested to buy in bulk, then the prospective buyer's country will send out his team's to see the extraction process, processing and the manufacture of ceramics in Banka Belitung Islands, whether the process carrying the environmental management and maintenance. For example, in kaolin mining reclamation, neutralization of waste in the process/kaolin beneficiation plant that will be created as the main material of ceramic. If everything has been fulfilled, then prospective buyer would book the ceramic goods.

Need to think about the existence of a mineral processing center integrated network of regional and international consortia that can produce a variety of mineral commodities handled by experts in metallurgy and materials which highly needed in the integrated upstreamdownstream value-added processing technology. This will be initially expensive, but will be able to respond to future challenges.

In the future view, some visions could be launhed as the followings :

"Go ocean" by utilizing the seas and the Exclusive Economic Zone (EEZ) (Figure 1), as a consortium that applies deep sea mining technology in order to take advantage of nodules or metal crust and marine industrial mineral deposits under the sea.

Republic of Indonesia territory is as far as 12 nautical miles from the point of the outer islands or a total area of 5.3 million $\mathrm{km}^{2}$, or 2 million $\mathrm{km}^{2}$ of land plus sea area of 3.3 million $\mathrm{km}^{2}$. With the EEZ the Indonesian exclusive economic region to 200 nautical miles, or an area of 8.4 million $\mathrm{km}^{2}$ or Indonesia area are 5.3 million $\mathrm{km}^{2}$ plus 2.3 million $\mathrm{km}^{2}$ and 0.8 million $\mathrm{km}^{2}$ area of the continental shelf. In international maritime law in the EEZ territory, Indonesia has the right to hold the exploration and exploitation of natural resources, for example mineral resources despite having to compete with other countries with the same rights.

Especially for Indonesia: "go east" to develop Eastern Indonesia Region, including Papua's Mamberamo River basin that has hydropower potential of over 15,000 MW as national key region, including metallurgical industries, such as iron smelting, steel by means of hydrogen reduction, alloy and the petrochemical industry also requires a lot of amount and type of minerals, especially industrial minerals (Soelistijo, et al., 1999).

Various problems faced in the field of mineral development in the future in globalization era that seems to be packaged in a management system that takes into account the fundamentals of user cost and scarcity rent is systemic in terms of (Soelistijo, et al., 2003, 2013, 2014) :

Government: as a regulator of creating and controlling the mineral resources development policy in the form of various laws with policy package include both incentives (i.e. to encourage intensification/exploration, application of appropriate technology in a value-added, downstream industrial development (super) and the use of local content, including the development of quality/skills of local human resources and disincentives (such as penalties for environmental quality neglect, including community development, primary commodities exporter), especially to create an attractive investment climate; as far as possible between countries globally, regionally and subregionally.

Industry (production-consumption): combines aspects of upstream and downstream in the supply chain of mineral resources utilization as mineral commodities solid and optimal, to support downstream industries to produce final goods containing the highest added value with optimal competitiveness.

- Region: there is a pattern resource development oriented to area systems (ecosystem), as indeed all development activities are in all space or region as the regional and subregional ecosystems where resources are located and utilized, in order to create development and economic convergence between regions.

- $\quad$ Science and technology (research and development): a subsystem that is an indicator of the modern human resources quality in the mastery of science and technology in order to divert the resources to meet its needs until the end of time.

- International aspects: that is an integration of regional subsystems in global or international chain where the global environment are to be considered in the management of a variety of interests both at 
the level of national and across-country or regional scale, to create a free trade and free investment with reasonable competition.

Policy direction in the development and utilization of minerals is one of the resource development efforts that support national development and further stage national development, in achieving the national goal can strengthen the national security of a country. National development and national defense are as the whole dynamic or one to each other are cohesively linked for the sustainability of a nation. The strategic geographical position of Indonesia located between two oceans (i.e. Indian Ocean and Pacific Ocean) and between two continents (i.e. Asia and Australia) where there are three SLOCs (Sea Link of Communication) across Indonesia Archipelago (Figure 1) could facilitate the fluency of international commodity trade including the products of downstream mineral industries in the future.

\section{Conclusion}

In the era of globalization where's the whole competitiveness in materials technology and world trade, Indonesia as a mineral resourceful country that located within the Pacific "ring of fire", needs to look for new opportunities to build mineral industry (hydrocarbon, metals and nometallic), among others, fine chemical industry, alloy (stainless steel), fiber, ceramic block, super/semiconductor industry to support the development of superdownstream industry which can produce a high added value products, and the processes in the downstream industry requires minerals as raw materials in large quantities and high quality. This added value of mineral and energy resource development as one of the very important measure is expected to be able to support the whole national efforts toward creating the value of national growth achievement and prestige as a whole at the utmost. And this potential benefit could be supported by the system what so called "the Indonesia incorporated" where the stakeholder is consisted of the government, the private (domestic as well as transnational) and the community as a whole.

\section{References}

[1] Anonymous (a), (2014). Gold-London Price Market Fix, http://www.kitco.com/scripts/hist_charts/yearly_graphs.plx, accessed April 14th.

[2] Anonymous (b), (2014). Non Ferrous Metals-Historical Data, http://www.lme.com/metals/nonferrous/historical_data, accessed April 14th

[3] Anonymous (c), (2014). OPEC Basket Price, http://www.opec.org/opec_web/en/data_graphs/40.htm, accessed April 14th.

[4] Anonymous (d), (2010). Industrial Minerals London.

[5] Anonymous (e), (2014). Indonesian Coal Reference Price, April.
[6] Anonymous (f), (2014).Natural Gas Spot and Futures Prices (NYMEX) Henry Hub, February.

[7] Anonymous (g), 2014, Gold-London Price Market Fix, http://www.kitco.com/scripts/hist_charts/yearly_graphs.plx, accessed April 14th, 2014.

[8] Anonymous (h), 2014, Non Ferrous Metals-Historical Data, http://www.lme.com/metals/non-ferrous/historical_data, accessed April 14th, 2014.

[9] Anonymous (i), 2014, OPEC Basket Price, http://www.opec.org/opec_web/en/data_graphs/40.htm, accessed April 14th, 2014.

[10] Badan Pusat Statistik, (2002). Statistik Indonesia, 2002. Jakarta.

[11] Badan Pusat Statistik, (2009). Statistik Indonesia, 2009. Jakarta.

[12] Badan Pusat Statistik,(1999). Statistik Indonesia, 1980 1999. Jakarta.

[13] Departemen Energi dan Sumber Daya Mineral, (2000). Buku Tahunan Pertambangan dan Energi 1999. Jakarta, Republik Indonesia.

[14] Departemen Energi dan Sumber Daya Mineral, (2004). Kebijakan Energi Nasional 2003-2020. Jakarta: Departemen Energi dan Sumber Daya Mineral.

[15] Direktorat Jenderal Minyak dan Gas Bumi, (1995). Data dan Informasi Minyak, Gas dan Panasbumi.Jakarta.

[16] Directorate of Mineral and Coal Enterprises, (2009). Indonesia Mineral \& Coal Statistics 2009. Jakarta. Directorate General of Geology and Mineral Resources, Ministry of Energy and Mineral Resources.

[17] K. Sayogyo, (1999). Migas dan Usaha Migas (Kumpulan Pokok-pokok Pikiran). Jakarta: Yayasan Patra Cendekia.

[18] L. Panggabean, (1983). Konsepsi Pengolahan Pasir Besi Yogyakarta; Konsultasi Teknik Pendayagunaan Syumber Daya Alam Untuk Mendukung Pengembangan Industri Besi Baja di Indonesia. Bandung: Badan Penelitian dan Pengembangan Industri, Departemen Perindustrian.

[19] M. Humphries, 2013, Rare Earth Elements: The Global Supply Chain

[20] R. Sumantri, (1991). Cadangan Migas Indonesia di Daerah Frontier Terutama Di Indonesia Bagian Timur. Jakarta: Pertamina.

[21] S. Padmanegara, and P. Silitonga, (1983). Potensi Bijih Besi Indonesia Untuk Pengembangan Industri Besi Baja; Konsultasi Teknik Pendayagunaan Sumber Daya Alam Untuk Mendukung Industri Besi Baja di Indonesia. Bandung: Badan Penelitian dan Pengembangan Industri, Departemen Perindustrian..

[22] S. Tirtosoekotjo, dan Suyartono, (1992). Meningkatkan Nilai Tambah Bahan Galian Industri, Dilihat Dari Aspek Teknologi, Bandung: Pusat Pengembangan Teknologi Mineral, Juni.

[23] U.W. Soelistijo, (1993). Peranan Litbang Teknologi Mineral Dalam Peningkatan Nilai Tambah. Seminar Mahasiswa Jurusan Tehnik Pertambangan, UNSRI. 
[24] U.W. Soelistijo, (1993). The Indonesia Challenge: The Added Value of Mineral Resources. Mineral Technology Research and Development Centre, Directorate General of Mines.

[25] U.W. Soelistijo, T. Suseno, I. Suherman, Mujib, C. Nas, (2003). Ekonomi Regional dan Model Penerapannya: Pengembangan Aumber Daya Mineral dan Energi Dalam Rangka Otonomi Daerah di Indonesia. Bandung: tekMIRA, Puslitbang Teknologi Mineral dan Batubara, Balitbang Energi dan Sumber Daya Mineral, Departemen Energi dan Sumber Daya Mineral.

[26] U.W. Soelistijo, and B. Santoso, (2003). A Brief Overview of The Scarcity of The Indonesia Gold Mining, Buletin Tekmira, ISSN 0854-7890, Nomor 28, Tahun 11, Bandung, Mei.

[27] U.W. Soelistijo, (2013). Economic Evaluation of the Existing and Potential Indonesian Coal Utilization. Earth Science.Vol. 2, No. 6, 2013, pp. 120-128. doi:10.11648/j.earth.20130206.12

[28] U.W. Soelistijo, (2013). Political Economy of Resources and Its Development: The Case of Indonesia. American Journal of Business,Economics and Management. Vol. 1, No. 1, 2013, pp. 16-24.
[29] U.W. Soelistijo, (2013). The Influence of Geopolitics and Strategical Factors upon the Development of Natural and Human Resources in Indonesia. Social Sciences. Vol. 2, No. 6, 2013, pp. 200-211. doi: 10.11648/j.ss.20130206.15

[30] U.W. Soelistijo, B.Santoso, T. Suseno, (2014). An Eye-Bird View of Facing Scarcity of Gold Mining in Indonesia. Scientia Research Library ISSN 2348-0416 USA CODEN: JASRHB Journal of Applied Science And Research, 2014, 2 (1):11.(http://www.scientiaresearchlibrary.com/arhcive.php)

[31] U.W. Soelistijo, (Editor), (1999). 13 Kawasan Pengembangan Ekonomi Terpadu di Kawasan Timur Indonesia dan 1 Kawasan Pengembangan Ekonomi Terpadu Sabang di Kawasan Barat Indonesia. Departemen Pertambangan dan Energi. (13 Integrated Economic Development Zones of Eastern Indonesia Region and 1 Sabang Integrated Economic Development Zopne of Western Indonesia Region. Departemnt of Mines and Energy.

[32] U.W. Soelistijo, (1991). Manajemen Teknologi. Jakarta: Sespanas LAN.

[33] W.C. Labys, (1973). Dynamics Commodity Models: Specification, Estimation, and Simulation. Lexington Books, D.C. Health and Company, Lexington, Massachusetts, Toronti, London, 